\title{
Szupersavak, metán és/vagy szén-monoxid reakcióinak in situ spektroszkópiai követése
}

\author{
HORVÁTH István Tamás* \\ Department of Chemistry, City University of Hong Kong, Kowloon, Hong Kong
}

\section{Bevezetés}

Oláh György magyar származású amerikai Nobel-díjas kémikus egyik legfontosabb felismerése az volt, hogy a metán szupersavak jelenlétében lejátszódó reakciói során ${ }^{1}$ elsőnek a metil karbónium kation, $\left[\mathrm{CH}_{5}\right]^{+},{ }^{2}$ képződik, amely alacsony stabilitása következtében vagy deprotonálódik vagy molekuláris hidrogént veszít. $\mathrm{Az}$ utóbbi esetben képződő metil karbénium kation, $\left[\mathrm{CH}_{3}\right]^{+}$, metánnal reagálva az etil karbónium kation, $\left[\mathrm{CH}_{3} \mathrm{CH}_{4}\right]^{+}$, kialakulását eredmé-nyezi. Hasonló reakciólépések és intermedierek képződése vezet az első stabil termék, a t-butil karbénium kation kialakulásához. ${ }^{3}$

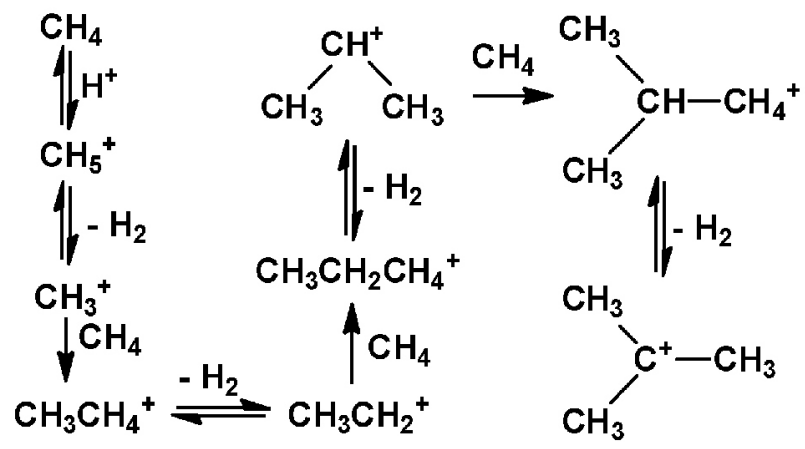

1. ábra. A t-butil karbénium kation kialakulása metán szupersavak jelenlétében lejátszódó reakciója során.

A metil karbónium kation gáz fázisban való létezését és szerkezetét infravörös spektroszkópiai módszerekkel ${ }^{4,5}$ és elméleti számításokkal ${ }^{6-9}$ tanulmányozták. A $\left[\mathrm{CH}_{5}\right]^{+}$ötös koordinációjú szénatomjához három hidrogén atom kételektronos-kétcentrumos kötéssel és két hidrogén atom egy kételektronos-három-centrumos kötéssel kapcsolódik (2a. ábra). A metil karbénium kation és a molekuláris hidrogén kételek-tronos kötése közötti kölcsönhatás szintén magyarázhatja a spektroszkópia adatokat (2b. ábra).

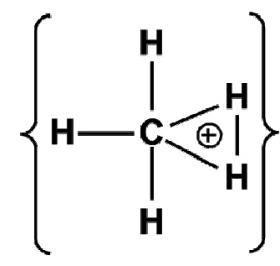

(a)

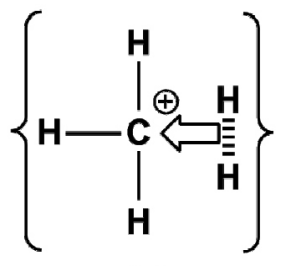

(b)
2. ábra. A metil karbónium kation két lehetséges szerkezete

\section{Metán reakciója szupersavakban}

A metil karbónium kation folyadék fázisban való létezését eddig még nem sikerült kisérletileg igazolni. A metán és $\mathrm{HF} / \mathrm{SbF}_{5}(1: 1)$ szupersav reakciójában mi is csak a $t$-butil karbénium kationt tudtuk kimutatni. ${ }^{10}$ Ezzel szemben az ezerszer kisebb savasságú $\mathrm{HSO}_{3} \mathrm{~F} / \mathrm{SbF}_{5}(1: 1)$ mágikus sav esetén a $t$-butil karbénium kation mellett $\mathrm{C}_{3-6}$ karbénium kationok is képződnek, jelezve, hogy a saverősség jelentősen befolyásolja az intermedierek és a termékek stabilitását. Fontos kiemelni, hogy a karbónium és karbénium kationok képződési mechanizmusának feltérképezése jelentősen hozzájárult a világürben található szénhidrogének eredetének megértéséhez. ${ }^{11}$

\section{Metán és szén-monoxid reakciója szupersavakban}

A földgáz szelektív és gazdaságos átalakítása a kémia egyik legizgalmasabb megoldásra váró kihívása. A lehetséges reakciók közül kiemelkedik a metán, szén-monoxid és $\mathrm{SbF}_{5}$ reakciója, amelyet a Shell kutatói irtak le 1969-ben. ${ }^{12}$ Az 50 şC-on végrehajtott reakció során az acílium ion, $\left[\mathrm{CH}_{3} \mathrm{CO}\right]^{+}$, és a „HSbF ${ }_{5}$ " szelektív keletkezését feltételezték, ${ }^{13}$ amelyet a vízzel vagy metanollal való feldolgozás során keletkező ecetsav vagy metilacetát kepződése igazolt (3. ábra).

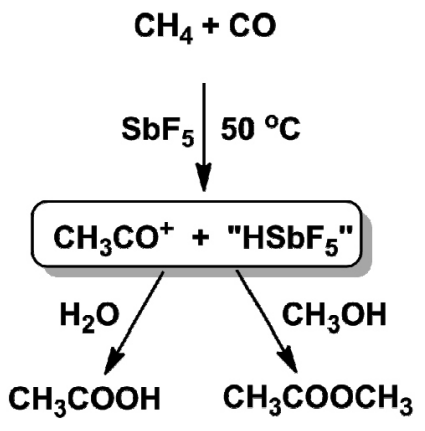

3. ábra. Metán és szén-monoxid reakciója $\mathrm{SbF}_{5}$-ben és a keletkező termék acílium ion reakciója vízzel és metanollal.

A metán és szén-monoxid alapú ecetsav gyártás természetesen sokkal olcsóbb lenne a napjainkban alkalmazott ródium vagy irídium katalizátorok jelenlétében végzett metanol karbonilezésnél.

Nagy-nyomású NMR kisérleteinket zafir egykristályból és titán fejjből készült csővekben végeztük. ${ }^{14} \mathrm{~A}$ metán és szén-monoxid reakciója mind a $\mathrm{HF} / \mathrm{SbF}_{5}(1: 1)$ mind a $\mathrm{HSO}_{3} \mathrm{~F} / \mathrm{SbF}_{5}(1: 1) \quad$ szupersavban az acílium ion kialakulá-sához vezetett (4. ábra). ${ }^{15}$ 


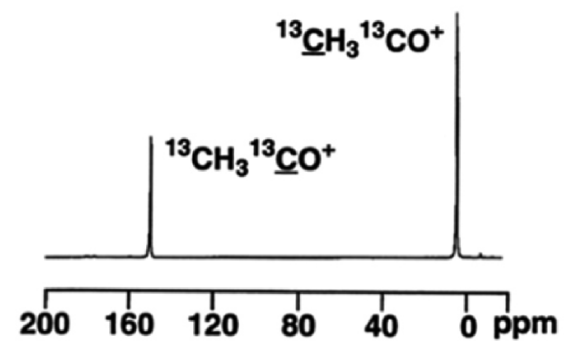

4. ábra. ${ }^{13} \mathrm{C}\left\{{ }^{1} \mathrm{H}\right\}$-NMR: $15 \mathrm{mmol} \mathrm{HF} / \mathrm{SbF} 5(1: 1), 34 \mathrm{~atm}{ }^{13} \mathrm{CH}_{4}$, 19 atm ${ }^{13} \mathrm{CO}, 80$ óra 80 şC-on.

Az acílium ion keletkezése mellett $\mathrm{SbF}_{3}$ és HF képződése is kimutatható volt, mely alapján a reakció stöchiometriája is meg lett határozva:

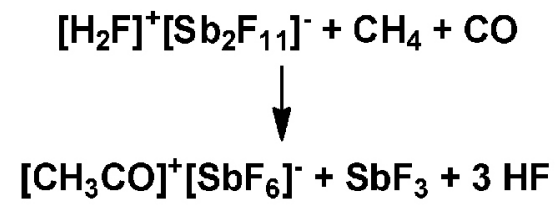

A két szupersavban történő reakciók között az a különbség, hogy az ezerszer savasabb $\mathrm{HF} / \mathrm{SbF}_{5}(1: 1)$ protonálja a szén-monoxidot és a formil kation, [HCO $]+{ }^{16}$ egyensúlyban van a formil fluorid $\mathrm{SbF}_{5}$ adduktjával (5. ábra). Ezzel szemben, a szén-monoxide nem protonálódik a $\mathrm{HSO}_{3} \mathrm{~F} / \mathrm{SbF}_{5}(1: 1)$ szupersavban és a formil fluorid $\mathrm{SbF}_{5}$ addukt sem képződik (6. ábra).

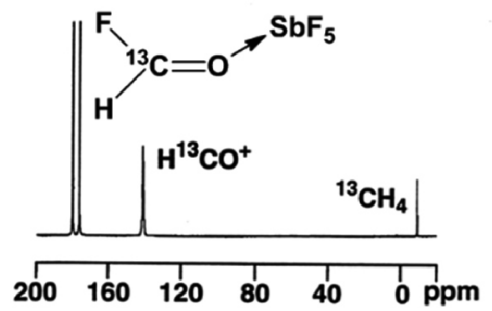

5. ábra. ${ }^{13} \mathrm{C}\left\{{ }^{1} \mathrm{H}\right\}$-NMR: $15 \mathrm{mmol} \mathrm{HF} / \mathrm{SbF} 5(1: 1), 34$ atm ${ }^{13} \mathrm{CH}_{4}$, 19 atm ${ }^{13} \mathrm{CO}, 25$ şC-on.

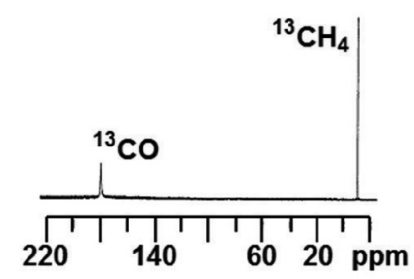

6. ábra. ${ }^{13} \mathrm{C}\left\{{ }^{1} \mathrm{H}\right\}$-NMR: $11.5 \mathrm{mmol} \mathrm{HSO} \mathrm{H}_{3} / \mathrm{SbF}_{5}(1: 1), 3.5 \mathrm{mmol}^{13} \mathrm{CH}_{4}$, $3.5 \mathrm{mmol}{ }^{13} \mathrm{CO}, 25$ şC-on.

A formil kation kisérleti észlelése nem várt eredmény volt, mivel korábban csak a gáz fázisban volt megfigyelhető. ${ }^{17,18}$ A folyadék fázisban való létezésének alaposabb igazolására számos nagy-nyomású infravörös és NMR spektroszkópiai kisérletet végeztünk. ${ }^{16}$
A HF/SbF 5 (1:1) szupersav IR spektrumát a ReactIR 1000 készülékkel vettük fel (7 ábra). A $2000 \mathrm{~cm}^{-1}$-től emelkedő alapvonalon kívül más sáv nem volt látható. Az oldat 28 atm szén-monoxid nyomás alá helyezése két új sáv megjelenését eredményezte. Amíg a $2110 \mathrm{~cm}^{-1}$-nél észlelt széles sáv a formil kationhoz, addig az $1671 \mathrm{~cm}^{-1}$-nél megjelent éles sáv a formil fluorid $\mathrm{SbF}_{5}$ adduktjához volt rendelhetö.

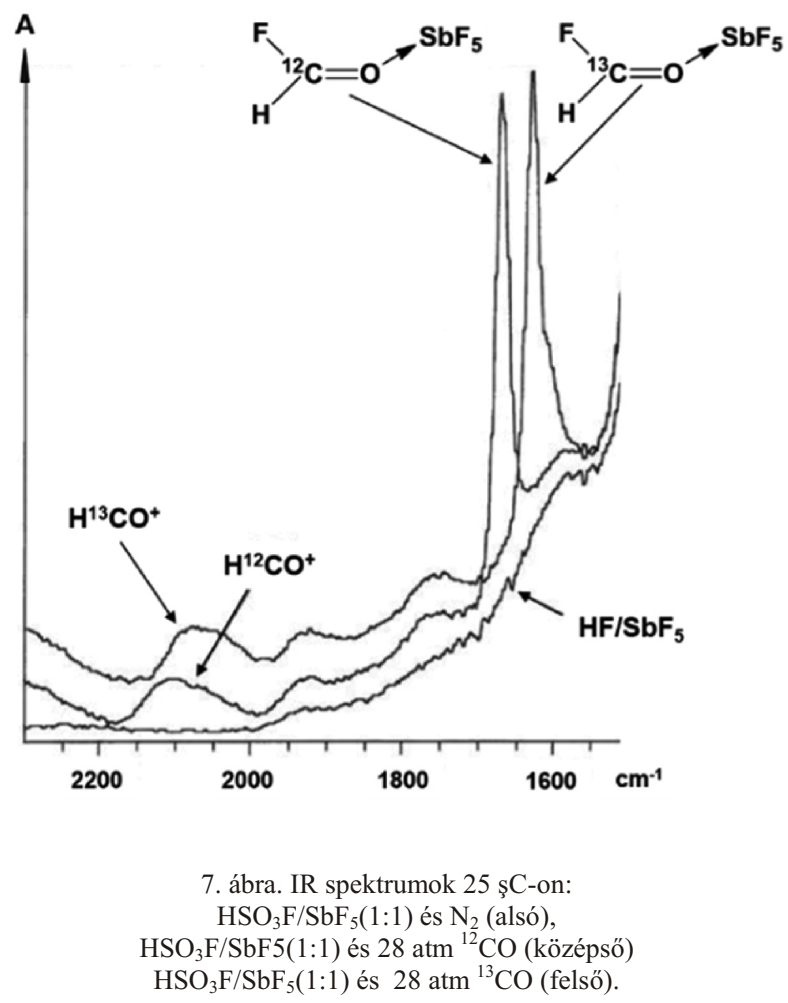

A hozzárendelést megerősítette a kísérlet ${ }^{13} \mathrm{CO}$-val történt megismétlése. A formil kation és a formil fluorid $\mathrm{SbF}_{5}$ adduktjának sávjai a várt eltolódást mutatva, 2060 és 1629 $\mathrm{cm}^{-1}$ hullámszám értékeknél jelentek meg.

Fontos kiemelni, hogy a $\left[\mathrm{H}^{13} \mathrm{CO}\right]^{+1} \mathrm{H}-\mathrm{NMR}$ jele 25 şC-on egy szinglet és a várt ${ }^{1} \mathrm{H}-{ }^{13} \mathrm{C}$ csatolás nem észlelhetô. $\mathrm{Ez}$ valószínüleg a $\mathrm{CO},[\mathrm{HCO}]^{+},[\mathrm{COH}]^{+}$és $[\mathrm{HCOH}]^{2+}$ között lejátszódó gyors egyensúlyi folyamatok erdeménye: ${ }^{16}$

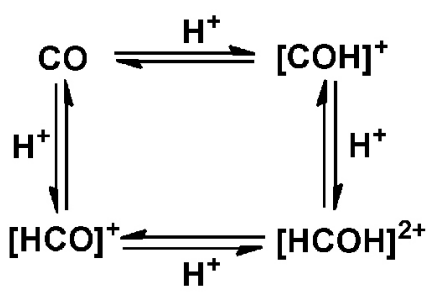

A metán és szén-monoxid szupersavban lejátszódó reakció magas szelektivitása azzal magyarázható, hogy az acílium kation protonnal vagy más karbónium vagy karbénium kationokkal való reakciója nem kedvezményezett. Noha egy pozitív töltésü intermedier, nem elég elektrofil ahhoz, hogy a metánnal reakcióba lépjen. 


\section{Személyes emlékek}

Oláh Györggyel 1980-as évek elejétől voltam kapcsolatban és gyakran találkoztunk konferenciákon. Beszélgetéseink a kémiáról hetekre elláttak gondolatokkal és a világról alkotott véleménye is maradandó nyomokat hagyott. Segítőkészsége és mindeki irányába megmutatkozó kedvessége híres volt. Emberként és tudósként is örök példa marad valamennyiünk számára.

\section{Hivatkozások}

1. Olah, G. A.; Schlosberg, R. H. J. Amer. Chem Soc. 1968, 90, 2726 - 2728. https://doi.org/10.1021/ja01012a066

2. Tal'roze, V. L.; Lyubimova, A. K. Dokl. Akad. Nauk. SSSR 1952, 86, $909-912$.

3. Olah, G. A. J. Amer. Chem Soc. 1972, 94, $808-820$. https://doi.org/10.1021/ja00758a020

4. White, E. T.; Tang, J.; Oka, T. Science 1999, 284, 135 137. https://doi.org/10.1126/science.284.5411.135

5. Asvany, O.; Yamada, K. M. T.; Brunken, S.; Potapov, A.; Schlemmer, S. Science, 2015, 347, 1346 - 1349. https://doi.org/10.1126/science.aaa3304

6. Marx, D.; Parrinello, M.; Nature 1995, 375, 216 - 218. https://doi.org/10.1038/375216a0

7. Schreiner, P. R.; Kim, S.-J.; Schaefer, H. F.; Schleyer, P. v. R. J. Chem. Phys. 1993, 99, $3716-3720$. https://doi.org/10.1063/1.466147

8. Scuseria, G. E. Nature 1993, 366, 512 - 513. https://doi.org/10.1038/366512a0

9. Muller, H.; Kutzelnigg, W.; Noga, J.; Klopper, W. J. Chem. Phys. 1997, 106, $1863-1869$. https://doi.org/10.1063/1.473340

\section{Köszönetnyilvánítás}

Ezúton is szeretnék köszönetet mondani John A. Gladysz-nak és Peter de Rege-nek a több éves együttmüködésükért. Köszönöm az Exxon Corporate Research (Annandale, New Jersey, USA) és az Amerikai Tudományos Alap (National Science Foundation, Washington DC, USA, CHE9401572) támogatását.

10. de Rege, P. J. F.; Gladysz, J. A.; Horváth, I. T. Abstracts of Papers of the ACS (Part 1, 203-INOR), 1998, 215, U761-U761.

11. Smith, D.; Adams, N. G. Astrophys. J. 1978, 220, L78 L92. https://doi.org/10.1086/182642

12. Hogoveen, H.; Lukas, J.; Roobek, C. F. Chem. Commun. 1969, 920-921. https://doi.org/10.1039/C29690000920

13. Hogoveen, H. Rec. Trav. Chim. 1967, 86, $809-815$. https://doi.org/10.1002/recl.19670860803

14. Horváth, I. T.; Ponce, E. C. Rev. Sci. Instrum. 1991, 62, 1104 - 1105. https://doi.org/10.1063/1.1142016

15. de Rege, P. J. F.; Gladysz, J. A.; Horváth, I. T. Adv. Synth. \& Cat. 2002, 344, $1059-1062$ https://doi.org/10.1002/1615-4169(200212)344

16. de Rege, P. J. F.; Gladysz, J. A.; Horváth, I. T. Science 1997, 276, $776-779$. https://doi.org/10.1126/science.276.5313.776

17. Woods, R. C.; Dixon, T. A.; Saykally, R. A.; Szanto, P. G. Phys. Rev. Lett. 1975, 35, $1269-1272$.

https://doi.org/10.1103/PhysRevLett.35.1269

18. Amano, T. J. Chem. Phys. 1983, 79, $3595-3599$. https://doi.org/10.1063/1.446216

\section{Monitoring the reactions of superacids, methane and/or carbon monoxide by in situ spectroscopy}

The reaction of alkanes with superacids, including the roles of carbonium and carbenium cations, was perhaps the most important discovery of Prof. George A. Olah, the late Hungarian-American Noble laurate. The reaction of methane with $\mathrm{HSF} / \mathrm{SbF}_{5}(1: 1)$ or $\mathrm{HSO}_{3} \mathrm{~F} / \mathrm{SbF}_{5}(1: 1)$ starts with the protonation of $\mathrm{CH}_{4}$ to results in the methyl carbonium cation, $\left[\mathrm{CH}_{5}\right]^{+}$, which either eliminate a proton or a molecular hydrogen. In the latter case, the resulting methyl carbenium ion, $\left[\mathrm{CH}_{3}\right]^{+}$, reacts with $\mathrm{CH}_{4}$ to yield the ethyl carbonium cation. The elimination of hydrogen from $\left[\mathrm{CH}_{3} \mathrm{CH}_{4}\right]^{+}$results in the ethyl carbenium cation, which reacts with methane to yield the normal-propyl carbonium cation. $\left[\left(\mathrm{CH}_{3} \mathrm{CH}_{2} \mathrm{CH}_{4}\right]^{+}\right.$eliminates molecular hydrogen to form iso-propyl carbenium cation. After the reaction of $\left[\left(\mathrm{CH}_{3}\right)_{2} \mathrm{CH}\right]^{+}$with methane, the product sec-butyl carbonium cation loses molecular hydrogen to yield the tert-butil carbenium cation, the first stable product in the superacid $\mathrm{HSO}_{3} \mathrm{~F} / \mathrm{SbF}_{5}(1: 1)$.

We have confirmed these results by recording a high-pressure ${ }^{13} \mathrm{C}\left\{{ }^{1} \mathrm{H}\right\}$-NMR of a solution of $12.5 \mathrm{mmol}$ $\mathrm{HF} / \mathrm{SbF}_{5}(1: 1)$ under $23.5 \mathrm{~atm}{ }^{13} \mathrm{C}-$ methane heated at $80 \mathrm{~s} \mathrm{C}$ for 16 hours. The two peaks at 335 and $42 \mathrm{ppm}$ can be assigned to the carbon atoms of the carbenium cation and the three methyl groups, respectively. In the case of the 1000 times less acidic $\mathrm{HSO}_{3} \mathrm{~F} / \mathrm{SbF}_{5}(1: 1)$, besides the presence of the tert-butil carbenium cation, a series of $\mathrm{C}_{3-6}$ carbenium cations formed, indicating that the acidity of the superacids has a major effect on the stability of the intermediates and products.

The mechanistic aspects of the chemistry of methane and other hydrocarbons in superacids have contributed significantly to the understanding of some of the most important acid catalyzed petrochemical processes in refineries as well as the origin of hydrocarbons in the universe.

When $\mathrm{HF} / \mathrm{SbF}_{5}(1: 1)$ or $\mathrm{HSO}_{3} \mathrm{~F} / \mathrm{SbF}_{5}(1: 1)$ were treated with 34 bar of ${ }^{13} \mathrm{C}$-methane and 19 bar ${ }^{13} \mathrm{C}$-carbon monoxide in a single crystal sapphire high-pressure NMR tube at $80 \mathrm{~s} C$ for 80 hours, the formation of acylium cation, $\left[\mathrm{CH}_{3} \mathrm{CO}^{+}\left[\mathrm{SbF}_{6}\right]^{-}\right.$, $\mathrm{SbF}_{3}$ and $\mathrm{HF}$ were observed. The acylium cation was identified by both NMR ( $\delta^{13} \mathrm{C}$ peaks at 149 and $\left.1 \mathrm{ppm}\right)$ and IR (bands at 1618 and $662 \mathrm{~cm}^{-1}$ ). The presence of side product $\mathrm{SbF}_{3}$ was confirmed by the IR bands at 619 and 575 $\mathrm{cm}^{-1}$. The in situ NMR has revealed the transient formation of the formyl cation, $\left[\mathrm{HCO}^{+}\left[\mathrm{SbF}_{6}\right]^{-}\right.$and the $\mathrm{SbF}_{5}$ adduct of 
formyl fluoride, $\mathrm{H}(\mathrm{F}) \mathrm{C}=\mathrm{O} \rightarrow \mathrm{SbF}_{5}$, immediately after the pressurization of the NMR tube with methane and carbon monoxide, even before heating the reaction mixture.

Accordingly, superacid $\mathrm{HF}_{\mathrm{SbF}}$ (1:1) reacts with ${ }^{13} \mathrm{C}$-carbon monoxide at room temperature to yield formyl cation, $\left[\mathrm{HCO}^{+}\left[\mathrm{SbF}_{6}\right]^{-}\left(\delta^{13} \mathrm{C}\right.\right.$ at $\left.149 \mathrm{ppm}\right)$ and the $\mathrm{SbF}_{5}$ adduct of formyl fluoride, $\mathrm{H}(\mathrm{F}) \mathrm{C}=\mathrm{O}>\mathrm{SbF}_{5}\left(\delta^{13} \mathrm{C}\right.$ at 179 $\mathrm{ppm})$. It should be noted that the ${ }^{1} \mathrm{H}-\mathrm{NMR}$ signal of the $\left[\mathrm{HCO}^{+}\left[\mathrm{SbF}_{6}\right]^{-}\right.$is a singlet and the expected ${ }^{1} \mathrm{H}-{ }^{13} \mathrm{C}$ coupling was not observable. This is probably due to the fast equilibria between $\mathrm{CO},[\mathrm{HCO}]^{+},[\mathrm{COH}]^{+}$and $[\mathrm{HCOH}]^{2+}$. These results were confirmed by monitoring the reaction with high-pressure infrared measurements using the ReactIR 1000 System (ASI Applied System Inc.). It should be noted that the 1000 times less acidic $\mathrm{HSO}_{3} \mathrm{~F} / \mathrm{SbF}_{5}$ (1:1) did not protonate the dissolved carbon monoxide (NMR: $\delta^{13} \mathrm{C}$ at 184 ppm), indicating the importance of the strength of the acid.

The carbonylation of methane with carbon monoxide in superacid $\left[\mathrm{H}_{2} \mathrm{~F}\right]^{+}\left[\mathrm{Sb}_{2} \mathrm{~F}_{11}\right]$ leads to the exclusive formation of the acylium cation, $\left[\mathrm{CH}_{3} \mathrm{CO}\right]^{+}\left[\mathrm{SbF}_{6}\right]^{-}$, the primary activation product, antimony trifluoride, $\mathrm{SbF}_{3}$ and three equivalents of hydrogen fluoride, HF. Thus, the electrophilic activation of methane leads to a cationic species, which is protected from further electrophilic activation. In addition, the acylium cation is not electrophilic enough to activate either methane or carbon monoxide. This approach therefore successfully combines full protection of the initial product from the species activating methane and fine-tuning the reactivity of the initial product resulting in total control of selectivity. 